\title{
Regulation of the strypsin-related proteinase ISP2 by progesterone in endometrial gland epithelium during implantation in mice
}

\author{
C. M. O'Sullivan, S. Y. Liu, S. L. Rancourt and D. E. Rancourt* \\ Southern Alberta Cancer Research Centre, Department of Biochemistry and Molecular \\ Biology, University of Calgary, Alberta T2N 4N1, Canada
}

\begin{abstract}
Hormones prepare the uterus for the arrival and subsequent invasion of the embryo during pregnancy. Extracellular matrix-degrading proteinases and their inhibitors are involved in this integration process. Recent genetic evidence indicates that there is redundancy within the implantation proteinase cascade, indicating that additional proteinases may be involved. Recently, we described a novel implantation serine proteinase (ISP1) gene that encodes the embryo-derived enzyme strypsin, which is necessary for blastocyst hatching in vitro and the initiation of invasion. The evidence presented in the present study indicates that a
\end{abstract}

second proteinase secreted from the uterus also participates in lysis of the zona pellucida. A second implantation serine proteinase gene (ISP2) was isolated, which encodes a related secreted tryptase expressed specifically within uterine endometrial glands. In pseudopregnancy, ISP2 gene expression is dependent on progesterone priming and is inhibited by the antiprogestin RU486. On the basis of similarities between ISP2 gene expression and that of a progesterone-regulated luminal proteinase associated with lysis of the zona pellucida, it is possible that the strypsinrelated protein, ISP2, may encode a zona lysin proteinase.

\section{Introduction}

Successful implantation and subsequent pregnancy require fine co-ordination of both maternal and embryonic factors (for reviews see Rinkenberger et al. (1997) and Carson et al. (2000)). Success depends on the synchronous development of the embryo and the uterus, so that at the appropriate time both participants are ready to interact. As the fertilized egg approaches the uterus it undergoes numerous divisions, culminating in the formation of a blastocyst. Simultaneously, the endometrium is undergoing proliferation in preparation for the arrival of the blastocyst, becoming most receptive to the attachment of trophoblast cells in a brief definitive period called the 'implantation window' (Psychoyos, 1973; Paria et al., 1993). In mice, this window of receptivity opens late on day 4 and closes early on day 5 . During this tight timing period, the blastocyst must shed its protective proteinaceous sheath, the zona pellucida, to begin fostering a relationship with the uterine deciduum.

In the mouse model, oestrogen and progesterone are necessary to synchronize the interaction of the embryo and uterus. Remnants of oestrogen released before ovulation stimulate the differentiation of uterine luminal and endometrial epithelia on the first 2 days of pregnancy (Martin et al., 1973). By day 3, increasing concentrations of progesterone prompt stromal cell proliferation, which is aided on the following day by a preimplantation surge of oestrogen (Huet-Hudson et al., 1989). This surge synchronizes

*Correspondence

Email: rancourt@acs.ucalgary.ca implantation by creating the window of receptivity, whereupon the uterus responds to tactile stimuli, either naturally by an embryo or artificially by an oil droplet (Finn, 1966), to develop a decidual cell differentiation response. If this surge does not occur (for example in ovariectomized females) hatched blastocysts are unable to attach and instead lie dormant in the uterus (Paria et al., 1993). Such delayed implantation can be overcome, within 20 days, by the administration of oestrogen if preceded by progesterone priming for 24-48 h (Yoshinaga and Adams, 1966).

In response to global regulation of implantation by oestrogen and progesterone, cytokines show local autocrine and paracrine effects and create a dialogue that operates largely between the endometrial glands, the luminal epithelium and the embryo. This dialogue is mediated through several vital cytokine networks including epidermal growth factor (EGF), leukocyte inhibitory factor (LIF), colony-stimulating factor (CSF) and insulin-like growth factor (IGF) (Regenstreif and Rossant, 1989; Pollard et al., 1991; Stewart et al., 1992; Baker et al., 1993; Das et al., 1994). In the early stages of pregnancy, before the establishment of the placenta, the endometrial glands serve as an important signalling centre producing several of these cytokines and their corresponding receptors.

Under the direction of cytokines, embryonic proteinases and their corresponding uterine inhibitors are regulated carefully to ensure controlled invasion of the deciduum by the trophoblasts (for review see Bischof et al. (2000)). Urokinase-type plasminogen activator (UPA) and matrix metalloproteinase 9 (MMP-9) were once thought to be critical proteinases in this process (Harvey et al., 1995; 
Alexander et al., 1996; Teesalu et al., 1996). However, gene disruption experiments have demonstrated that such proteinases are dispensable and indicate that implantation operates under conditions of genetic redundancy (Carmeliet et al., 1994; Vu et al., 1998). In the search for additional proteinases in implantation we have identified two implantation serine proteinase genes, ISP1 and ISP2, encoding novel and distinct secreted tryptases. O'Sullivan et al. (2001) provided functional data indicating that ISP1 encodes the embryo-derived hatching enzyme, strypsin, and demonstrated that this enzyme plays an additional role in the initiation of implantation. In the present study, the expression of ISP2 tryptase in glandular epithelium during zona lysis and implantation in vivo was investigated.

\section{Materials and Methods}

\section{Animals and treatments}

CD1 mice were obtained at the age of 6-7 weeks from Charles River Canada (St Constant, PQ) and maintained in a standard laboratory animal facility with controlled temperature $\left(20^{\circ} \mathrm{C}\right)$ and lighting (lights on between 07:00 $\mathrm{h}$ and 19:00 h). The maintenance and treatment of the animals were in full compliance with standard laboratory animal care protocols approved by the University of Calgary's Animal Care Committee.

Natural pregnancies were obtained by pairing female mice with adult males and checking the female mice daily for the presence of a vaginal copulatory plug as an indication of mating. For embryo collection, day 0.5 corresponded to mid-day of the day on which a vaginal plug was detected. Pregnant dams were killed on a specific day by cervical dislocation, after which uteri and oviducts were removed surgically before isolation of embryos, either by dissection or flushing (Hogan et al., 1994).

All surgical procedures were performed after the mice were anaesthetized with an i.p. injection of Avertin $(2 \%$ (w/v) tribromoethanol; Aldrich Chemical Co, Milwaukee, WI). Ovariectomy was performed by dorsal-lateral incision (Hogan et al., 1994).

Ovariectomized mice were allowed at least 1 week to recover before the induction of deciduomas. All steroid hormones including RU486 were dissolved in sesame oil and injected s.c. At each stage of the experiment, control mice were used that received only oil ( $0.1 \mathrm{ml}$ per mouse) injections. Three animals were treated and analysed in each experiment.

The standard regimen for artificial induction of deciduomas (Finn, 1966) was modified to mimic pseudopregnancy more closely (Milligan et al., 1995). Here, the first progesterone treatment was started 2 days after exposure to oestrogen. This modified regimen consisted of $100 \mathrm{ng}$ oestrogen administered once a day starting on day 0 , and $1 \mathrm{mg}$ progesterone plus $10 \mathrm{ng}$ oestrogen from day 3 onwards. Deciduomas were induced surgically on day 5 (between 14:00 $\mathrm{h}$ and $16: 00 \mathrm{~h})$ by injecting sesame oil $(10 \mu \mathrm{l})$ into the lumen of one uterine horn from its oviductal tip. Injected and uninjected uterine horns were collected 24,48 or 72 h later for histological sectioning and in situ hybridization analysis.

Delayed implantation was induced and maintained by ovariectomized mice on day 3 of pregnancy, followed by administration of progesterone ( $2 \mathrm{mg}$ per mouse) on days 4-6. Subsequently, half of these mice were treated with oestrogen (25 ng per mouse) on the morning of day 7 , while the other half received the normal progesterone injection. Mice were killed $24 \mathrm{~h}$ later for analysis by in situ hybridization.

The effect of steroids on uterine development was examined by ovariectomizing pregnant mice and treating them with hormone injections either immediately or after a 2 week recovery period. Mice received injections of either progesterone (1 mg per mouse), oestrogen (100 ng per mouse), or a combination of both (10 ng oestrogen and $1 \mathrm{mg}$ progesterone per mouse) for 3 days. The mice were then killed on the morning of day 4. Superovulated pregnant and pseudopregnant mice (Hogan et al., 1994) were treated with RU486 (400 $\mu \mathrm{g}$ per mouse) on the morning of day 3 after a vaginal plug was detected to determine further the importance of progesterone on ISP2 gene expression. The mice were killed $24 \mathrm{~h}$ later and their uterine horns were collected for in situ hybridization analysis.

\section{Embryo culture}

Morulae were collected from oviducts of superovulated day 2.5 pregnant dams in M2 medium (Hogan et al., 1994). For in vitro hatching, morulae (approximately 100) were cultured in microwells for approximately $24 \mathrm{~h}$ at $37^{\circ} \mathrm{C}, 5 \%$ $\mathrm{CO}_{2}$ in KSOMaa medium (Erbach et al., 1994). For in vitro embryo outgrowth onto extracellular matrix, hatched blastocysts (approximately 100) were cultured for an additional $48 \mathrm{~h}$ at $37^{\circ} \mathrm{C}, 5 \% \mathrm{CO}_{2}$ in Dulbecco's modified Eagle's medium plus $5 \%(\mathrm{v} / \mathrm{v})$ fetal bovine serum on microwells coated with extracellular matrix derived from $10 \%(\mathrm{v} / \mathrm{v})$ Triton X-100-treated mouse embryo fibroblasts (Behrendtsen et al., 1995).

\section{Embryo RNA preparation}

Total RNA was collected from a litter (approximately ten) of embryos plus deciduum (day 6.5 implantation sites), embryos (days 8.5, 11.5 and 13.5 of gestation) and placentae (days 11.5 and 13.5) using Trizol (Life Technologies, Rockville, MD). In vitro hatching blastocysts (at 50\% hatch) were collected by centrifugation at $3000 \mathbf{g}$ for 5 min for Trizol RNA preparation (O'Sullivan et al., 2001). RNA from blastocysts outgrowing in vitro was collected by Trizol lysis directly in microwells (O'Sullivan et al., 2001). Poly (A)+ RNA was enriched from day 6.5 embryo plus deciduum total RNA using oligo (dT) cellulose chromatography (Sambrook et al., 1989).

\section{cDNA cloning and sequence analysis}

A 478 bp ISP2 PCR subfragment derived previously by active site degenerate PCR (O'Sullivan et al., 2001) was 
used to screen $5 \times 10^{5}$ recombinants from a day 6.5 embryo plus deciduum library in $\lambda \mathrm{GT} 10$, and resulted in the identification of two cDNA clones bearing a $1.2 \mathrm{~kb}$ insertion. The $1.2 \mathrm{~kb}$ EcoRI fragment was subcloned into pBKCMV (Stratagene, La Jolla, CA) for cycle sequencing (PE Biosystems, Foster City, CA). The nucleotide sequence was translated into protein sequence using the Swiss Protein ExPAsy tool (http://expasy.cbr.nrc.ca/tools/dna.html). Nine serine proteinase peptides identified from a BLAST identity search were aligned with ISP2 using Clustal W (Higgins, 1994; http://dot.imgen.bcm.tmc.edu: 9331/multi-align/ multi-align.html) and compared to develop a dendrogram using the protein parsimony method (http://bioweb.pasteur.fr/ seqanal/phylogeny/phylip-uk.html).

\section{Expression analysis}

Poly (A)+ RNA (5 $\mu \mathrm{g}$ ) from day 6.5 murine embryo plus deciduum was subjected to electrophoresis through a $1.2 \%$ $(\mathrm{w} / \mathrm{v})$ formaldehyde-agarose gel alongside an RNA high molecular mass ladder (Life Technologies). After transfer to Hybond $\mathrm{N}^{+}$(Amersham Pharmacia, Piscataway, $\mathrm{NJ}$ ), the membrane was probed with the $1.2 \mathrm{~kb}\left[{ }^{32} \mathrm{P}\right]$-labelled ISP2 cDNA clone.

The presence of ISP2 transcripts in embryos and placentae was monitored using RT-PCR. Total RNA $(1 \mu \mathrm{g})$ was reverse-transcribed and amplified using ISP2-specific primers (ISP2 for $_{\text {f }}$ 5'-TGTGAGCCGGGTCATCATCC-3'; ISP2 $2_{\text {rev }}$ : $5^{\prime}$-GGCATTGTGGTACATCTCCT-3') and 40 rounds of thermal cycling $\left(1 \mathrm{~min}\right.$ at $94^{\circ} \mathrm{C}, 2 \mathrm{~min}$ at $60^{\circ} \mathrm{C}$ and $2 \mathrm{~min}$ at $72^{\circ} \mathrm{C}$ ). The RT-PCR amplification of GAPDH (as a control for mRNA loading) was performed as described by Arcellana-Panlilio and Schultz (1993). The predicted $360 \mathrm{bp}$ and $175 \mathrm{bp}$ amplification products were separated on a $2 \%(\mathrm{w} / \mathrm{v})$ agarose gel.

Whole embryo and sectioned RNA in situ hybridization using digoxigenin-labelled RNA probes were performed essentially as described by Rancourt and Rancourt (1997). Uteri from nonpregnant, pregnant and pseudopregnant mice (see above) were fixed in $4 \%(\mathrm{w} / \mathrm{v})$ paraformaldehyde, embedded in paraffin wax and cut into sections $(7 \mu \mathrm{m}$ thickness). The ISP2 probe comprised the 478 bp RT-PCR subclone in $\mathrm{pBSKS}^{+}$. The antisense probe was synthesized using T3 polymerase after plasmid linearization with EcoRI. The sense probe was synthesized using T7 polymerase after plasmid linearization with BamHI. All experiments were performed in parallel with the sense RNA probe to detect non-specific hybridization.

\section{Results}

ISP2 represents another novel branch of the tryptase subfamily of $S 1$ proteinases

After evidence of genetic redundancy within the implantation proteinase cascade was found we initiated experiments to identify additional serine proteinases that may play a vital role in implantation. Active site RT-PCR of
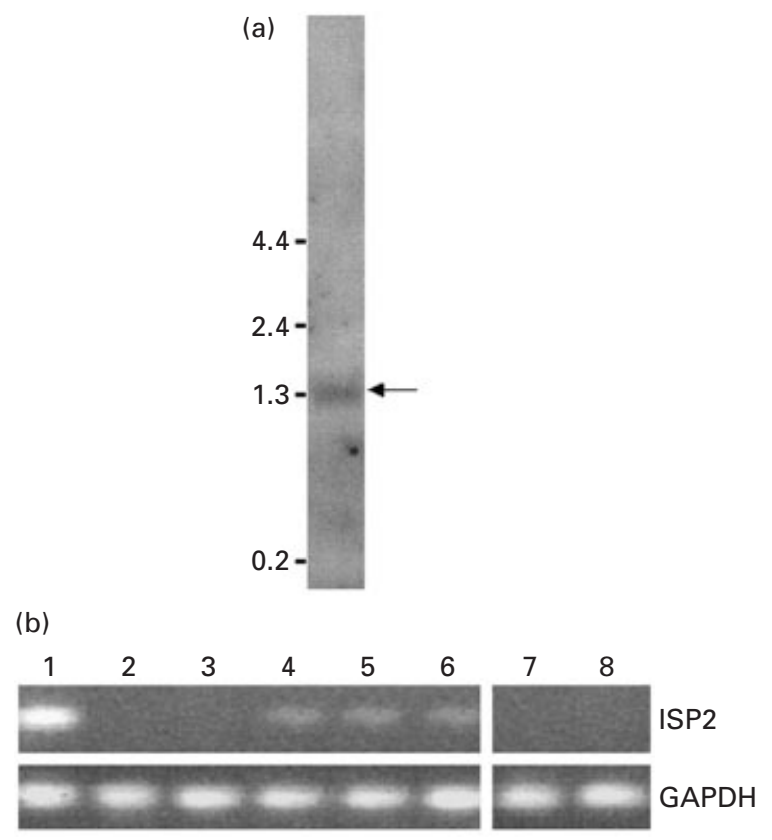

Fig. 1. Implantation serine proteinase (ISP2) gene expression during implantation and embryogenesis in mice. (a) Northern blot analysis of day 6.5 embryo plus deciduum poly(A)+ RNA (5 $\mu \mathrm{g})$ revealed a mRNA species of $1.3 \mathrm{~kb}$ when hybridized with a random prime-labelled 1.2 kb ISP2 cDNA clone. (b) ISP2 (360 bp; upper panel) and GAPDH (175 bp; lower panel) expression in embryogenesis as detected by RT-PCR. ISP2 gene expression is strong in day 6.5 implantation sites (lane 1) and is absent in embryo RNA from day 8.5 (lane 2) and day 11.5 (lane 3) pregnancies. ISP2 gene expression is moderate in placental RNA from day 11.5 (lane 4) and day 13.5 (lane 6) pregnancies, and in embryo RNA from a day 13.5 (lane 5) pregnancy. It is not detected in RNA from hatching (lane 7) or outgrowing (lane 8) blastocysts.

material from day 6.5 implantation sites was used to reveal two genes encoding novel implantation serine proteinases, ISP1 and ISP2 (O'Sullivan et al., 2001). A 478 bp ISP2 cDNA fragment derived from active site RT-PCR was used to screen a day 6.5 mouse embryo plus deciduum cDNA library (O'Sullivan et al., 2001) and a $1.2 \mathrm{~kb}$ cDNA clone was isolated. On the basis of prior analysis of ISP1, which also gave rise to a $1.2 \mathrm{~kb}$ cDNA clone, it was suspected that a full length cDNA clone for ISP2 had also been isolated. This idea was confirmed by northern blot analysis of day 6.5 embryo plus deciduum poly $(\mathrm{A})^{+}$, which revealed a single $1.3 \mathrm{~kb}$ mRNA species when hybridized with the $1.2 \mathrm{~kb}$ ISP2 cDNA clone (Fig. 1a).

Sequence analysis of ISP2 revealed a predicted protein of 290 amino acids (Fig. 2). In BLAST identity searches (Fig. 2; Altschul et al., 1997), it was found that ISP2 shared a moderate amount of sequence similarity with ISP1 $(46 \%$ amino acid identity; O'Sullivan et al., 2001) and haematopoietic tryptases (MMCP6, 45\% amino acid 
ISP2

ISP1

MMCP-6

TRYP-1

RMCP-7

TESTISIN

ISP2

ISP1

MMCP-6

TRYP-1

RMCP-7

TESTISIN

ISP2

ISP1

MMCP-6

TRYP-1

RMCP-7

TESTISIN

ISP2

ISP1

MMCP-6

TRYP-1

RMCP-7

TESTISIN

\section{ISP2}

ISP1

MMCP-6

TRYP-1

RMCP-7

TESTISIN

ISP2

ISP1

MMCP-6

TRYP-1

RMCP-7

TESTISIN

\section{$\downarrow$}

1 - - - - MLIQZCLTLF FUGC S I TTPAPGP - - - -EDVLMGIVGGHSAPQGKWPWQVSLR

1 - - - -MFRLLLLAL S CLESTVFFMASVS IS - - - -RSKPVGIVGGQR TP PGKWPWQVSLR

1 - - MLKRRLLLLWAL S L A SLVY SAPRP- - - - ANQRVG IVGGHEASE SKWPWQVSLR

1 - - - - NLLLLALPVLASRAYAAPAPGQ-- - ALORVGIVGGQEAPR SKWPWQVSLR

1 - - - - MLKLLLLTLPLLSSLVHAAPSL- - - - AMPREG IVGGQEASGNKWPWQVSLR

1 MGARGALLLALLLARAGLR RESQEAAPL SGPCGRRVITSRIVGGEDAELGRWPWQGSLR

50 IYRYYWA FWVIINCGGSIIHPQWVLTAAHCIRERDADPSVFRIRVGEAY- - - - -LYGGK 50 MYSYAVNSWVHICGGSIIHPQWILTAAHCIQSQDADPAVYRVQVGEVY-- - - -LYKEQ

51 FK- - LNYWIHFCGGSLIHPQWVLTAAHCVGPHIKSPQLFRVQLREQY--- - - -LYYGD

48 VH - - -GPYWMHFCGGSLIHPQWVLTAAHCVGPDVKDLAALRVQLREQH - - - - - -LYYQD

48 VN---DTYWMHFCGG-SIHPQWVLTAAHCVGPNKADPNKLRVQLRKQY- - - - - -LYYHD

61 LWDS---- HVC GVSLL SHRWALTAAHCFETDL SDPS GWMVQFGQLTSMP SFW SLQA YY

103 ELLSVSRVIIHPDFVHAGLGSDVALLQLAVSV̄QSF PNVKPVKLPSESLEVTKKDVCWVTC

103 ELLNISRIIIHP DYNDVSKRFDLALMQLTAXLVTSTNVSPVSLPKDS TTFDSTDQCWLVG

101 QLLSLNR IVVH PHYYTAEGGA DVALLELEVPVNVSTHIHPISLPPASETFPPGTSCWVTG

98 QLLPVSRIIVHPQFYTAQIGADIALLELEEPVNVSSHVHTVTLPPASETFPPGMPCWVTG

97 HLLTVSQI ISHPDFYIAQDGADIALLKLTNPVNITSNVHTVSLPPASETFPSGTLCWVTG

115 TRY FVSNIYLSPRYLGNSP-YDIALVKLSAPVTYTKHIQPICLQASTFEFENRTDCWVTG

Fig. 2. Predicted amino acid sequence for implantation serine proteinase (ISP2) in mice and alignment with other similar serine proteinases. Identical amino acids are marked by black boxes and conservative substitutions are noted by grey boxes. ISP2 is most similar to ISP1 (46\% identity) and mouse mast cell proteinase 6 (MMCP-6) (45\% identity). Chymotrypsin and murine elastase both share $34 \%$ identity with ISP2. Arrows indicate predicted pre- and pro- cleavage sites. The S1 proteinase active site consensus sequences His ([LIVM]-[ST]-A-[STAG]-H-C) and Ser [DNSTAGC]-[GSTAPIM VQH]-x(2)-G-[DE]-S-G-[GS][SAPHV]-[LIVMFYWH]-[LIVMF YSTANQH]) are underlined. Tryp-1: human tryptase 1; RMCP-7: rat mast cell proteinase 7; testisin: eosinophil serine proteinase 1.

identity; Lutzelschwab et al., 1997). Other mast cell proteases showed similar degrees of sequence identity. The next closest subfamilies contain chymotrypsins and elastases with approximately $34 \%$ shared amino acid identity. Like ISP1, the relationship of ISP2 to the S1 peptidase family is clear, as it shares the conserved His and Ser active site moieties (IHPQW and GDSGGPL), in addition to the common N-terminal sequence (IVVG) of mature tryptases (Fig. 2; Smyth et al., 1996). Maximum parsimony analysis (Higgins, 1994) indicates that, based on the low degree of similarity between the ISPs and their nearest neighbours within the mast cell tryptase family, the
ISPs represent a distinct branch of the S1 proteinase superfamily that diverged from the elastase/chymotrypsin and mast cell proteinase clusters at approximately the same time (dendrogram not shown).

\section{Temporal expression of ISP2 during gestation}

RT-PCR was used to characterize the expression of ISP2 throughout gestation (Fig. 1b). High expression was observed in day 6.5 embryo plus deciduum RNA consistent with the expression observed using northern blotting. Lower expression was also observed in placental RNA isolated 
from day 11.5 and day 13.5 pregnancies. ISP2 gene expression was not observed in RNA from the embryo proper at days 8.5 and 11.5 ; a residual amount of expression was detected at day 13.5. This pattern of expression for ISP2 resembled that previously identified for ISP1 (O'Sullivan et al., 2001). On the basis of the role of ISP1 in blastocyst hatching and outgrowth onto extracellular matrix, it was investigated whether ISP2 is expressed in the blastocyst and plays a similar role to ISP1. However, RT-PCR of RNA isolated from blastocysts hatched or outgrown in vitro indicated that ISP2 was not expressed in early embryos (Fig. 1b). This result was confirmed by additional in situ hybridization experiments performed on morulae and blastocysts, which indicated that ISP2 is not expressed (data not shown). On the basis of these expression results, it was concluded that the function of ISP2 was distinct from that of ISP1 and it was hypothesized that the function of ISP2 resided within the uterine deciduum during implantation.

\section{Expression of ISP2 in glandular epithelium during implantation}

In situ hybridization analysis of saggital sections was performed to confirm that ISP2 gene expression originated from the deciduum. Throughout the peri-implantation period, intense ISP2 mRNA staining was observed specifically within endometrial gland epithelium (Fig. 3). Expression was first identified in saggital sections of day 6.5 implantation sites (not shown) and subsequently in implantation sites of day 7.5 and day 8.5 pregnancies (Fig. $3 a, b)$. At day 6.5 , ISP2 mRNA staining was also observed between implantation sites lying remote from the embryo (Fig. 3c). These results first indicated the possibility that ISP2 gene expression might not be dependent upon decidua surrounding the implantation site. Interestingly, ISP2 mRNA staining was not observed in nonpregnant uterus (Fig. 3d), indicating that ISP2 gene expression occurred specifically in response to pregnancy. ISP2 gene expression was also not observed on day 2.5 (Fig. 3e), when the morula is oviductal, or on day 3.5 (Fig. 3f), when the blastocyst enters the uterus. However, ISP2 mRNA staining was observed at days 4.5 and 5.5 (Fig. $3 \mathrm{~g}, \mathrm{~h}$ ), when the implantation window is opened. These results indicate that ISP2 expression occurs either in response to the implantation reaction or is regulated hormonally in synchrony with implantation.

\section{ISP2 gene expression in pseudopregnancy}

The potential role of hormones and the decidualization reaction in regulating ISP2 gene expression was investigated further by inducing artificial pregnancies in ovariectomized females using uterine oil injections after progesterone and oestrogen priming (Finn, 1966; Milligan et al., 1995). As part of the experimental design, oil was introduced into only one uterine horn to ensure that the decidualization reaction occurred on one side of the animal only. The other side served to control for the potential role of hormonal
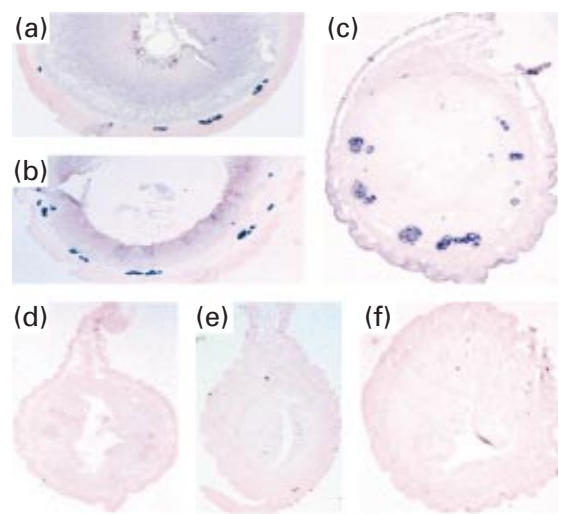

(f)

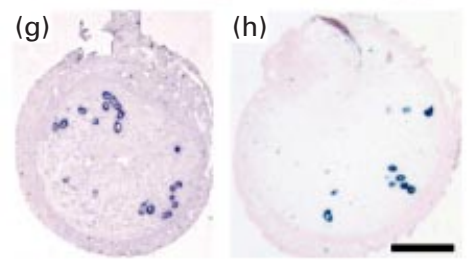

(h)

Fig. 3. Implantation serine proteinase (ISP2) gene expression in mouse endometrial glands during implantation. Uteri from pregnant and virgin dams were sectioned saggitally and hybridized in situ with a digoxigenin-labelled ISP2 probe. ISP2 mRNA staining is observed in endometrial glands during implantation. ISP2 mRNA staining is observed distally in (a) day 7.5 and (b) day 8.5 sites. (c) ISP2 gene expression is also observed between implantation sites at day 6.5. ISP2 is not observed in (d) nonpregnant uterus or uterus from (e) day 2.5 or $(\mathrm{f})$ day 3.5 pregnancies. It is first observed in uterus from (g) day 4.5 and (h) day 5.5 pregnancies. Scale bar represents $500 \mu \mathrm{m}$.

treatments on ISP2 gene expression. After in situ hybridization, ISP2 mRNA staining was observed in both uterine horns, indicating that ISP2 gene expression also occurs during artificial pregnancy and in the absence of decidualization (Fig. 4).

\section{Induction of ISP2 gene expression by progesterone}

The influence of steroid hormones was examined using models of pregnancy and pseudopregnancy. In delayed implantation experiments, ISP2 gene expression was abrogated by ovariectomy (Fig. 5a). However, when progesterone was administered to maintain pregnancy, normal ISP2 expression was observed (Fig. 5b). A similar maintenance of ISP2 gene expression was not observed in the presence of oestrogen only (Fig. 5c). These results indicate that there is probably a requirement for progesterone in maintaining ISP2 gene expression during pregnancy.

Mice were treated with RU486 on day 3 of pregnancy or pseudopregnancy and analysed for ISP2 gene expression in uterine sections to confirm the requirement of progesterone for uterine ISP2 gene expression. When mice were killed on the following day, normal ISP2 mRNA staining was observed in vehicle-treated control mice (Fig. 6a,c). 


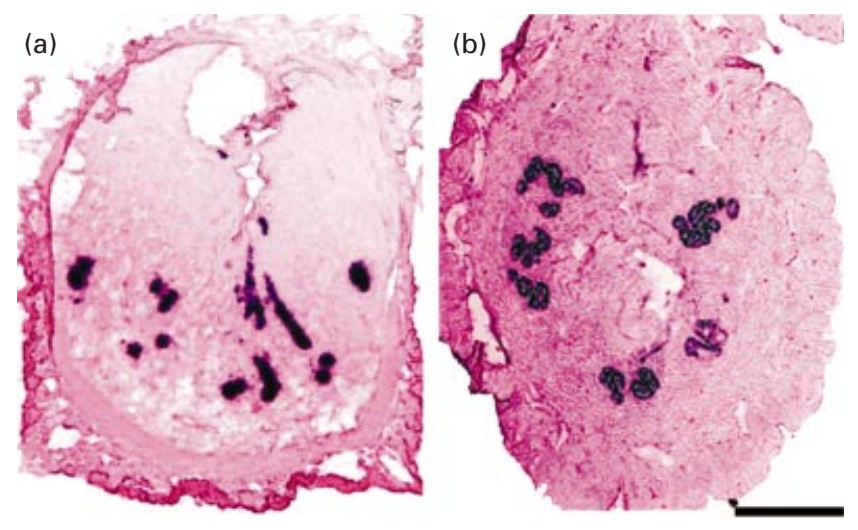

Fig. 4. Decidualization-independent implantation serine proteinase (ISP2) gene expression in uterus of pseudopregnant mouse. Ovariectomized dams were primed with progesterone and oestrogen, after which a single horn was injected with sesame oil to induce a number of artificial decidualizations. After in situ hybridization, ISP2 gene expression was observed in both the (a) decidualized and (b) non-decidualized uterine horn of pseudopregnant females. Scale bar represents $500 \mu \mathrm{m}$.

However, in mice treated with the antiprogestin, ISP2 mRNA staining was not observed (Fig. 6b,d). These results established the necessity of progesterone for maintaining ISP2 gene expression in pregnancy.

Interestingly, ISP2 gene expression could be induced by progesterone after the cessation of pregnancy by ovariectomy (Fig. $5 \mathrm{~d}$ ). In the absence of progesterone maintenance after ovariectomy, ISP2 gene expression was not observed (data not shown). However, when pregnancy failure was induced by ovariectomy, ISP2 gene expression could still be induced up to 14 days after ovariectomy (Fig. 5d). These results confirmed that after ovariectomy and a long absence of progesterone signalling, the uterus remains responsive to progesterone, and indicates that ISP2 gene expression may be induced by progesterone.

Similar experiments also demonstrated that oestrogen did not have a stimulatory or inhibitory effect on ISP2 gene expression. After ovariectomy in the absence of progesterone maintenance, it was observed that oestrogen did not have a stimulatory effect on ISP2 gene expression (Fig. 5f). Moreover, administration of oestrogen in combination with progesterone after induced pregnancy failure resulted in no significant alteration of ISP2 gene expression (Fig. 5d) compared with that of progesterone treatment only. These results indicate that progesterone alone is necessary and sufficient to bring about maximal ISP2 gene expression.

\section{Discussion}

In previous studies, active site RT-PCR was used to identify a serine proteinase of the subtilisin lineage, SPC6, which functions in decidua during implantation (Rancourt and Rancourt, 1997). In the present study and in an accompanying study (O'Sullivan et al., 2001), active site RT-PCR was used to identify novel serine proteinases of the chymotrypsin lineage that are involved in implantation or embryonic development. Before the beginning of this work, urokinase and tissue type plasminogen activator had both been characterized in implantation and embryogenesis (Strickland et al., 1976). Our PCR strategy showed that four additional serine proteinases are expressed during implantation, granzyme $D$ and $F$, the functions of which are currently unknown (Smyth et al., 1996; Allen and NilsenHamilton, 1998) and two novel implantation serine proteinases, ISP1 and ISP2. O'Sullivan et al. (2001) demonstrated that ISP1 encodes a novel embryo-derived tryptase that functions in blastocyst hatching and initiation of invasion into extracellular matrix. The aim of the present study was to characterize ISP2 structure and expression during implantation.

DNA sequencing of a full-length cDNA clone of ISP2 derived from a day 6.5 embryo plus deciduum cDNA library demonstrated that the ISP2 gene also encodes a novel serine proteinase related to tryptases. Although the ISPs have hallmark signatures of tryptases, maximum parsimony analysis indicates that the ISPS represent a distinct lineage of the SP1 superfamily, having first diverged from the mast cell proteinase and elastase/chymotrypsin clusters at approximately the same time. The evolution of these tryptases is consistent with the suggestion that the ISPs play overlapping roles in zona lysis and implantation (see below).

The data obtained in the present study indicate that during gestation the ISP2 gene is expressed predominantly during implantation, although residual expression is observed in the developing placenta. Unlike ISP1, the ISP2 gene is not expressed in the pre-implantation embryo. Instead, ISP2 gene expression was observed in endometrial gland epithelium throughout the peri-implantation period (days 4.5-8.5). During implantation, it was observed that ISP2 gene expression occurs initially in glands throughout the decidua, including regions proximal to the embryo, but is progressively restricted when the glands decrease in size and move to the periphery of the uterine crypt during deciduum regression and placentation.

In situ hybridization experiments revealed that ISP2 gene expression might be regulated by progesterone. Hybridization of ISP2 mRNA within glandular epithelium lying between implantation sites first indicated the possibility that ISP2 gene expression might not be dependent on the presence of the embryo. This possibility was confirmed when oil-induced deciduomata were established in hormonally treated pseudopregnant females, whereupon ISP2 mRNA was observed within the glands of nondecidualized control horns. Further investigation using ovariectomy and models of delayed implantation demonstrated that ISP2 gene expression was dependent on progesterone administration only, and that oestrogen showed no effect either on its own or in combination with progesterone. ISP2 gene expression was abrogated in both pregnancy and pseudopregnancy in the presence of the 

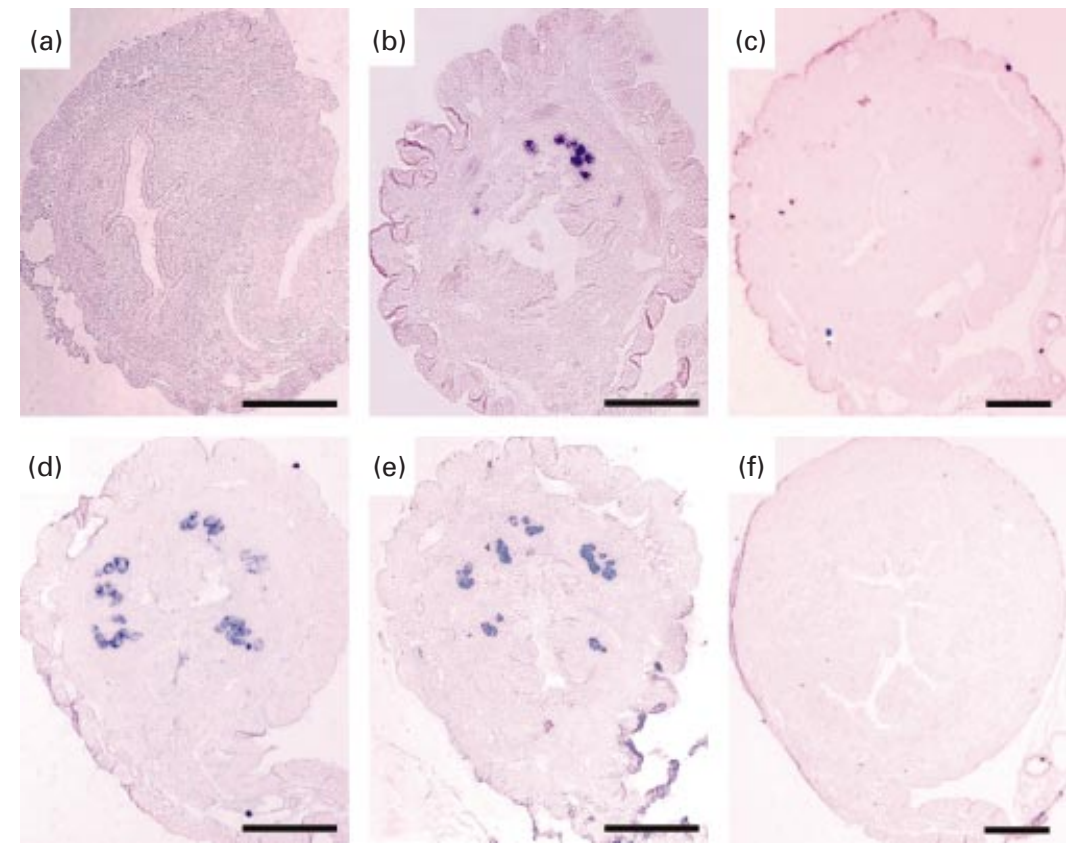

Fig. 5. Uterine implantation serine proteinase (ISP2) gene expression in hormonetreated, ovariectomized pregnant female mice. Pregnant dams were ovariectomized, treated immediately $(\mathrm{a}, \mathrm{b}, \mathrm{c})$ or after a 2 week recovery period $(\mathrm{d}, \mathrm{e}, \mathrm{f})$ with combinations of $(a)$ vehicle, $(b, d)$ progesterone only, $(c, f)$ oestrogen only and (e) progesterone plus oestrogen and monitored for uterine ISP2 gene expression using in situ hybridization. ISP2 gene expression was observed in endometrial glands when females were exposed to progesterone or progesterone plus oestrogen, but not when exposed to vehicle or oestrogen only. No ISP2 mRNA staining is observed in ovariectomized pregnant mice treated with (a) vehicle or (c) after oestrogen supplementation only. (b) ISP2 mRNA staining is observed in endometrial glands of ovariectomized pregnant mice treated immediately with progesterone. (d) ISP2 gene expression is induced by progesterone treatment after ovariectomy and prolonged absence of progesterone. (e) Administration of oestrogen, in addition to progesterone, does not result in a further increase of ISP2 gene expression. (f) After ovariectomy and prolonged absence of progesterone, ISP2 mRNA staining is not observed when mice are treated with oestrogen only. Scale bar represents $500 \mu \mathrm{m}$.

anti-progestin, RU486. These data indicate that glandular ISP2 gene expression is regulated positively by progesterone. At this time, it is unclear whether the effect of progesterone on ISP2 gene expression is direct.

A key feature of successful implantation is the synchrony between embryonic and endometrial development. This synchrony is achieved through timely preparation, regulated first by hormones and, after zona lysis, by cytokine signalling between the endometrium and the embryo. Only on day 4 of pregnancy, as progesterone concentrations increase, does the glandular epithelium differentiate and become secretory (Duc-Goiran et al., 1999; Paria et al., 1999). The in situ hybridization experiments performed in the present study have demonstrated that ISP2 mRNA is not detected at stages before the endometrial gland secretory phase. These observations indicate that ISP2 secretion into the glandular and uterine lumen may occur as a consequence of progesterone-induced epithelial differentiation.
In the pregnancy setting, the endometrial gland acts as a 'command centre', sending and receiving cytokine dispatches that support implantation. LIF, for example, is secreted from the endometrial gland into the uterine lumen, where it is thought to interact with luminal LIF receptors and result in the presentation of EGF receptors that are necessary for apposition of the embryo (Song et al., 2000). As observed for ISP2, the LIF gene is not expressed after RU486 administration (Danielsson et al., 1997; Ghosh et al., 1998; Liu et al., 1999). RU486 has a profound effect on preventing the differentiation of secretory glandular epithelium, which probably accounts for its effect on LIF expression and in preventing implantation (Greb et al., 1999). However, LIF secretion is distinct from ISP2 in that it is also oestrogendependent (Song et al., 2000). Although oestrogen appears to co-ordinate expression of LIF during the 'window of implantation', a morphologically normal endometrial gland is necessary for secretion into the lumen. This role for 

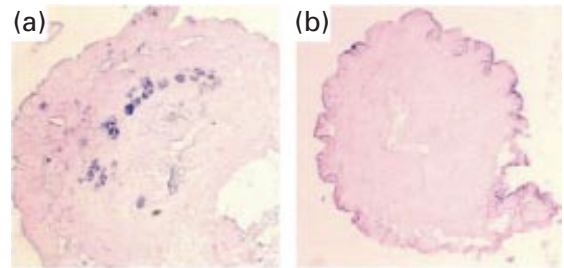

(c)

(d)

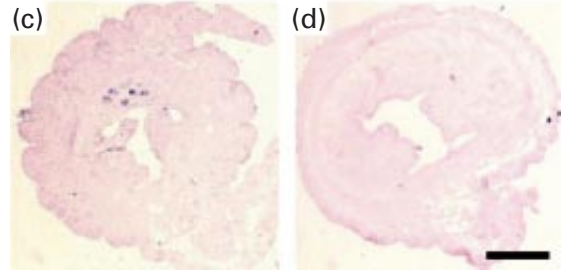

Fig. 6. Implantation serine proteinase (ISP2) mRNA is not detected in pregnant and pseudopregnant mouse uterus after RU486 treatment. Uteri from $(\mathrm{a}, \mathrm{c})$ vehicle- and $(\mathrm{b}, \mathrm{d}) \mathrm{RU} 486$ - treated $(\mathrm{a}, \mathrm{b})$ pregnant and $(\mathrm{c}, \mathrm{d})$ pseudopregnant dams were sectioned saggitally and hybridized in situ with a digoxigenin-labelled ISP2 probe. (a) ISP2 mRNA staining is observed in the vehicle-treated pregnant uterus. (b) No ISP2 mRNA staining is observed in the RU486treated pregnant uterus. (c) ISP2 mRNA staining is observed in the vehicle-treated pseudopregnant uterus. (d) No ISP2 mRNA staining is observed in pseudopregnant RU486-treated uterus. Scale bar represents $500 \mu \mathrm{m}$.

progesterone in generating a fully functional endometrial gland explains why progesterone priming is required before the oestrogen pulse in delayed implantation. As ISP2 gene expression is independent of the oestrogen spike and occurs during the progesterone-priming phase, it is likely that the first proteolytic role of ISP2 may precede implantation.

In addition to ISP2, the matrix metalloproteinase, MMP-9, and the serine proteinase, kallikrein 1, are also expressed in glandular epithelium during implantation and are found in uterine luminal fluid (Jeziorska et al., 1996; Corthorn et al., 1997). Although these proteinases are presumed to participate in the extracellular matrix remodelling that occurs during implantation, the role of ISP2 at this time is unclear. As MMP-9 is activated by tryptases in vivo (Keski-Oja et al., 1992; Lohi et al., 1992), part of the function of ISP-2 protein may lie in activating luminal MMP-9. In addition, a direct role for ISP2 in matrix remodelling is also possible. O'Sullivan et al. (2001) demonstrated that ISP1 tryptase participates in the extracellular matrix degradation that occurs during blastocyst outgrowth. Accordingly, the potential matrix remodelling activity of ISP2 might also be direct.

It is not known how ISP2 may be recruited to participate in matrix degradation at the implantation site. One mechanism may be that ISP2 encodes a second enzyme associated with lysis of the zona pellucida (see O'Sullivan et al., 2001). The ISP1 gene encodes the enzyme, strypsin, which is associated with the focal hatching of blastocysts in vitro. However, there is increasing evidence to indicate that the 'focal' hatching observed in vitro is distinct from the zona 'lysis' that occurs in vivo (Gonzales and Bavinster, 1995; Montag et al., 2000; Gonzales et al., 2001). Accordingly, it has been suggested that a distinct 'lysin' protein occurs in luminal fluid before implantation. Interestingly, lysin activity is dependent upon an intact ovary and progesterone (Joshi and Murray, 1974; Denker, 1977), yet does not require the presence of an embryo within the uterus (Orsini and McLaren, 1967). Although it has been suggested that kallikrein 1 may participate in zona lysis, this hypothesis is inconsistent with the expression profile of kallikrein 1, which is downregulated by progesterone and dependent on the presence of the embryo. Instead, based on the striking similarity in expression profiles between lysin and ISP2, in addition to the relationship of ISP2 tryptase to the embryo-derived hatching enzyme strypsin, it is possible that the ISP2 gene may encode a lysin proteinase.

On the basis of the observation that tryptases multimerize for activity (Huang et al., 2000), O'Sullivan et al. (2001) suggested that ISP1 proteinase (approximately 27 kDa) must multimerize to yield active strypsin (approximately $70 \mathrm{kDa})$. Zymography has also revealed a $70 \mathrm{kDa}$ proteinase doublet in uterine flushings of pregnant hamsters (Gonzales et al., 2001). Although it has been suggested that this doublet may represent strypsin, as strypsin is only observed in blastocysts, this suggestion is inconsistent with the presence of this doublet in uterine flushings of pseudopregnant females. Instead, this $70 \mathrm{kDa}$ species may represent multimers of ISP2. Nonetheless, this suggestion still does not account for the observation of a second doublet (45 kDa), which is expressed in a narrow window around the time of zona lysis. While this doublet may represent a smaller form of the $70 \mathrm{kDa}$ species (an ISP2 dimer), another proteinase associated with zona lysis may yet be found.

The observation that two related tryptases are derived separately from the embryo and uterus to effect zona lysis reiterates the hypothesis that genetic redundancy has evolved to ensure successful implantation. Given that hatching constitutes a serious block in assisted reproduction (De Vos and Van Steirteghem, 2000), the further characterization of the roles of ISP1 and ISP2 tryptases in hatching and implantation is of utmost importance.

The authors would like to thank J. Cross, M. Hollenberg and G. Schultz for their advice and comments. The authors would also like to thank B. Wong and $\mathrm{H}$. Toft for assistance in generating uterine tissue from artificial pregnancies and D. Demetrick with help in photography. B. Carson, E. Rattner and J. Turnbull provided technical assistance. This work was funded by the Alberta Cancer Board and the Canadian Institutes of Health Research (Operating Grant 14702). C. M. O'Sullivan is supported by an Alberta Cancer Board Studentship and by The William H. Davies Scholarship (University of Calgary). D. E. Rancourt is a Scholar of the Alberta Heritage Foundation for Medical Research. Accessation no. AF305425. 


\section{References}

Alexander CM, Hansell EJ, Behrendsten O, Flannery ML, Kishani NS, Hawkes SP and Werb Z (1996) Expression and function of matrix metalloproteinases and their inhibitors at the maternal-embryonic boundary during mouse embryo implantation Development 122 1723-1736

Allen MP and Nilsen-Hamilton M (1998) Granzymes D, E, F, and G are regulated through pregnancy and by IL-2 and IL-15 in granulated metrial gland cells Journal of Immunology $1612772-2779$

Altschul SF, Madden TL, Schaffer AA, Zhang J, Zhang Z, Miller W and Lipman DJ (1997) Gapped BLAST and PSI-BLAST: a new generation of protein database search programs Nucleic Acids Research 25 3389-3402

Arcellana-Panlilio MY and Schultz GA (1993) Analysis of messenger RNA Methods in Enzymology 225 303-328

Baker J, Liu JP, Robertson EJ and Efstratiadis A (1993) Role of insulin-like growth factors in embryonic and postnatal growth Cell 75 73-82

Behrendtsen O, Alexander CM and Werb Z (1995) Cooperative interactions between extracellular matrix, integrins and parathyroid hormonerelated peptide regulate parietal endoderm differentiation in mouse embryos Development 121 4137-4148

Bischof P, Meisser A and Campana A (2000) Mechanisms of endometrial control of trophoblast invasion Journal of Reproduction and Fertility Supplement 55 65-71

Carmeliet P, Schoonjans L, Kieckens L et al. (1994) Physiological consequences of loss of plasminogen activator gene function in mice Nature 368 419-424

Carson DD, Bagchi I, Dey SK, Enders AC, Fazleabas AT, Lessey BA and Yoshinaga K (2000) Embryo implantation Developmental Biology 223 217-237

Corthorn J, Figueroa C and Valdes G (1997) Estrogen and luminal stimulation of rat uterine kallikrein Biology of Reproduction $\mathbf{5 6}$ 1432-1438

Danielsson KG, Swahn ML and Bygdeman M (1997) The effect of various doses of mifepristone on endometrial leukaemia inhibitory factor expression in the midluteal phase - an immunohistochemical study Human Reproduction 12 1293-1297

Das SK, Wang XN, Paria BC, Damm D, Abraham JA, Klagsbrun M, Andrews GK and Dey SK (1994) Heparin-binding EGF-like growth factor gene is induced in the mouse uterus temporally by the blastocyst solely at the site of its apposition: a possible ligand for interaction of blastocyst EGF receptor in implantation Development 120 1071-1083

Denker HW (1977) Implantation: the role of proteinases and blockage of implantation by proteinase inhibitors Advances in Anatomy, Embryology and Cell Biology 53 3-123

De Vos A and Van Steirteghem A (2000) Zona hardening, zona drilling and assisted hatching: new achievements in assisted reproduction Cells, Tissues and Organs 166 220-227

Duc-Goiran P, Mignot TM and Ferre BF (1999) Embryo-maternal interactions at the implantation site: a delicate equilibrium European Journal of Obstetrics and Gynecology and Reproductive Biology 83 85-100

Erbach GT, Lawitts JA, Papaioannou VE and Biggers JD (1994) Differential growth of the mouse preimplantation embryo in chemically defined media Biology of Reproduction 50 1027-1033

Finn CA (1966) Endocrine control of endometrial sensitivity during the induction of the decidual cell reaction in the mouse Journal of Endocrinology 36 239-248

Ghosh D, Kumar PG and Sengupta J (1998) Effect of early luteal phase administration of mifepristone (RU486) on leukaemia inhibitory factor, transforming growth factor beta and vascular endothelial growth factor in the implantation stage endometrium of the rhesus monkey Journal of Endocrinology 157 115-125

Gonzales DS and Bavinster BD (1995) Zona pellucida escape by hamster blastocysts in vitro is delayed and morphologically different compared to zona escape in vivo. Biology of Reproduction 52 470-480

Gonzales DS, Bavinster BD and Mese SA (2001) In utero and in vitro proteinase activity during the Mesocricetus auratus embryo zona escape time window Biology of Reproduction 64 222-230
Greb RR, Kiesel L, Selbmann AK, Wehrmann M, Hodgen GD, Goodman AL and Wallwiener D (1999) Disparate actions of mifepristone (RU486) on glands and stroma in the primate endometrium Human Reproduction $\mathbf{1 4}$ 198-206

Harvey MB, Leco KJ, Arcellana-Panillo MY, Zhang X, Edwards DR and Schultz GA (1995) Proteinase expression in early mouse embryos is regulated by leukaemia inhibitory factor and epidermal growth factor Development 121 1005-1014

Higgins DG (1994) CLUSTAL V: multiple alignment of DNA and protein sequences Methods in Molecular Biology 25 307-318

Hogan B, Beddington R, Costantini F and Lacy E (1994) Manipulating the Mouse Embryo: A Laboratory Manual. Cold Spring Harbor Laboratory Press, Cold Spring Harbor, New York

Huang C, Morales G, Vagi A et al. (2000) Formation of enzymatically active, homotypic and heterotypic tetramers of mouse mast cell tryptases. Dependence on the conserved Trp-rich domain on the surface Journal of Biological Chemistry 275 351-358

Huet-Hudson YM, Andrews GK and Dey SK (1989) Cell type-specific localization of c-Myc protein in the mouse uterus: modulation by steroid hormones and analysis of the peri-implantation period Endocrinology 125 1683-1690

Jeziorska M, Nagase H, Salamonsen LA and Woolley DE (1996) Immunolocalization of the matrix metalloproteinases gelatinase B and stromelysin 1 in human endometrium throughout the menstrual cycle Journal of Reproduction and Fertility 107 43-51

Joshi MS and Murray IM (1974) Immunological studies of the rat uterine fluid peptidase Journal of Reproduction and Fertility 37 361-365

Keski-Oja J, Lohi J, Tuuttila A, Tryggvason K and Vartio T (1992) Proteolytic processing of the 72,000-Da type IV collagenase by urokinase plasminogen activator Experimental Cell Research 202 471-476

Liu CQ, Yuan Y, Wang ZX and Lu SH (1999) Mifepristone regulation of leukemia inhibitory factor and uterine receptivity in rabbits Contraception 60 309-312

Lohi J, Harvima I and Keski-Oja J (1992) Pericellular substrates of human mast cell tryptase: 72,000 dalton gelatinase and fibronectin Journal of Cell Biology 50 337-349

Lutzelschwab C, Pejler G, Aveskogh M and Hellman L (1997) Secretory granule proteases in rat mast cells. Cloning of 10 different serine proteases and carboxypeptidase $\mathrm{A}$ from various rat mast cell populations Journal of Experimental Medicine 185 13-29

Martin L, Das RM and Finn CA (1973) The inhibition by progesterone of uterine epithelial proliferation in the mouse Journal of Endocrinology $\mathbf{5 7}$ 549-554

Milligan SR, Cohen PE and Finn CA (1995) The minimum requirements for oestradiol to induce uterine sensitivity for implantation and decidualization in mice Human Reproduction 10 1502-1506

Montag M, Koll B, Holmes P and van der Ven H (2000) Significance of the number of embryonic cells and the state of the zona pellucida for hatching in mouse blastocysts in vitro versus in vivo. Biology of Reproduction 62 1738-1744

Orsini MW and McLaren A (1967) Loss of the zona pellucida in mice, and the effect of tubal ligation and ovariectomy Journal of Reproduction and Fertility 13 485-499

O'Sullivan CM, Rancourt SL, Liu SY and Rancourt DE A novel murine tryptase involved in blastocyst hatching and outgrowth Reproduction 122 61-71

Paria BC, Huet-Hudson YM and Dey SK (1993) Blastocyst's state of activity determines the "window" of implantation in the receptive mouse uterus Proceedings National Academy of Sciences USA 90 10159-10162

Paria BC, Tan J, Lubahn DB, Dey SK and Das SK (1999) Uterine decidual response occurs in oestrogen receptor $\alpha$-deficient mice Endocrinology $1402704-2710$

Pollard JW, Hunt JS, Wiktor-Jedrzejczak W and Stanley ER (1991) A pregnancy defect in the osterpetrotic (op/op) mouse demonstrates the requirements for CSF-1 in female fertility Developmental Biology $\mathbf{1 4 8}$ 273-283

Psychoyos A (1973) Endocrine control of egg implantation. In Handbook of Physiology pp 187-215 Eds RO Greep, EG Astwood and SR Geiger. American Physiological Society, Washington, DC 
Rancourt SL and Rancourt DE (1997) Murine subtilisin-like proteinase SPC6 is expressed during embryonic implantation, somitogenesis and skeletal formation Developmental Genetics 21 75-81

Regenstreif LJ and Rossant J (1989) Expression of the C-fms proto-oncogene and of the cytokine, CSF-1, during mouse embryogenesis Developmental Biology 133 284-294

Rinkenberger JL, Cross JC and Werb Z (1997) Molecular genetics of implantation in the mouse Developmental Genetics 21 6-20

Sambrook J, Fritsch EF and Maniatis T (1989) Molecular Cloning: A Laboratory Manual. Cold Spring Harbor Laboratory Press, Cold Spring Harbor, New York

Smyth MJ, O'Conner MD and Trapani JA (1996) Granzymes: a variety of serine protease specificities encoded by genetically distinct subfamilies Journal of Leukocyte Biology 60 555-562

Song H, Lim H, Das SK, Paria BC and Dey SK (2000) Dysregulation of EGF family of growth factors and $\mathrm{COX}-2$ in the uterus during the preattachment and attachment reactions of the blastocyst with the luminal epithelium correlates with implantation failure in LIF-deficient mice Molecular Endocrinology 14 1147-1161

Stewart CL, Kaspar P, Brunet LJ, Bhatt H, Gadi I, Kontgen F and
Abbondanzo SJ (1992) Blastocyst implantation depends on maternal expression of leukemia inhibitory factor Nature 359 76-79

Strickland S, Reich E and Sherman MI (1976) Plasminogen activator in early embryogenesis: enzyme production by trophoblast and parietal endoderm Cel/ 9 231-240

Teesalu T, Blasi F and Talarico D (1996) Embryo implantation in mouse: fetomaternal coordination in the pattern of expression of UPA, UPAR, PAI-1 and a2MR/LRP genes Mechanisms of Development 56 103-116

Vu TH, Shipley JM, Bergers G, Berger JE, Helms JA, Hanahan D, Shapiro SD, Senior RM and Werb Z (1998) MMP-9/gelatinase B is a key regulator of growth plate, angiogenesis and apoptosis of hypertrophic chondrocytes Cel/ 93 411-422

Yoshinaga K and Adams CE (1966) Delayed implantation in the spayed progesterone-treated adult mouse Journal of Reproduction and Fertility 12 593-595

Received 15 January 2001.

First decision 9 March 2001.

Accepted 20 April 2001. 